\title{
RANCANG BANGUN ALAT UJI KEAUSAN BERBASIS SISTEM KONTAK DISC-ON-DISC
}

\author{
Ady Setiawan', J. jamari ${ }^{2}$, Marwan Effendy ${ }^{3}$, Dimas Ardiansyah ${ }^{4}$ \\ Jurusan Teknik Mesin, Universitas Muhammadiyah Surakarta \\ JI. A. Yani, Pabelan, Kartasura, Tromol Pos 1, Kota Surakarta, Indonesia \\ Adysetiawan890@yahoo.com¹, jjamari123@yahoo.com², marwaneffendy123@yahoo.com², \\ dimasardiansyah123@yahoo.com ${ }^{4}$
}

\begin{abstract}
Abstrak
Keausan merupakan fenomena hilangnya matrial dari permukaannya ke bagian yang lain atau bergeraknya matrial pada suatu suatu permukaan atau perpindahan permukaan dengan berjalanya waktu yang lama kelamaan keausan ini akan menimbulkan kerusakan pada komponen mekanik yang saling bergesekan. Untuk meningkatkan umur dari kerusakan komponen-komponen mekanik, maka permasalahan keausan ini perlu dikaji lebih lanjut. Didalam ilmu tribology para peneliti membagi proses terjadinya keausan akibat kontak mekanik tersebut menjadi tiga bagian, yaitu meliputi bahan, lingkungan, kondisi operasi, dan geometri permukaan benda yang terjadi keausan. Untuk mengetahui secara cepat kondisi dari keausan tersebut diperlukan alat uji tribometer. Penelitian ini difokuskan pada rancang bangun alat uji keausan berbasis sistem kontak disc-on-disc. Alat ini dipakai untuk menguji komponen yang terdiri dari dua piringan (disc-on-disc) dimana material tersebut dapat divariasikan jenisnya. Perancangan mekanisme sisi kontak permukaannya pada arah radial sehingga piringan tersebut dapat berputar (rolling contact) dan alat uji ini dapat divariasikan beban maupun putaran. Untuk itu metode perancangan konsep matrik dapat memberikan keputusan yang akan diambil, dengan metode ini semua konsep produk akan dinilai dari parameter konstruksi konsep, perancangan produk, dan konsep produk terbaik yang akan dikembangkan menjadi sebuah produk. Pengujian dilakukan secara eksperimen untuk mengetahui terjadinya keausan yang terjadi, mulai dari kondisi awal hingga kondisi kontinyu. Hasil rancangan menunjukan bahwa alat uji layak digunakan untuk menentukan parameter parameter keauasan yang terjadi. Dengan variasi jumlah putaran (maksimal $2800 \mathrm{rpm}$ ), gaya tekan hingga $1000 \mathrm{MPa}$, dan kecepatan putaran spesimen yang dapat diatur, maka gaya gesek pada permukaan spesimen dapat diketahui, sedangkan variabel yang diukur adalah koefisien akibat dari rolling contact .
\end{abstract}

Kata kunci: wear, friction, rolling contact, disc-on-disc.

\section{PENDAHULUAN}

Dalam dunia permesinan secara luas bahwa roda kereta api dan rel mengalami kerusakan permukaan seperti keausan dan kelenturan kontak bergulir dalam proses servis interaksi roda/rel. Meskipun retakan roda/rel dan perbaikan material telah menurunkan tingkat keausan dari kedua elemen, keausan mungkin masih merupakan masalah yang relatif besar terutama pada jalur kereta api. Akan menjadi lebih serius jika terjadi kegagalan dalam pelumasan. Keausan roda kemudi dan sudut pengukur rel merupakan keutamaan (main cost) dalam pemeliharaan kereta api. Oleh karena itu, penyelidikan perilaku penggunaan roda/rel dan simulasi evolusi profil roda/rel sangat penting dan signifikan untuk mengembangkan teknologi pemeliharaan rel yang optimal, dimana keseimbangan antara pelumasan roda/rel, penggerusan rel dan putaran periode yang dijadwalkan harus sepatutnya [1].

Penggunaan roda / kereta api telah dipelajari secara ekstensif melalui penelitian laboratorium dan di lapangan. 
Penelitian di lapangan dilakukan dengan mengumpulkan sejumlah besar data keausan roda/rel di jalur pengkeretapian, namun banyak mengalami kesulitan. Selain hal tersebut, alasan biaya dalam penelitian lapangan memaksa peneliti untuk melakukan tes laboratorium, jika memungkinkan [2].

Dalam tes laboratorium [3], tingkat keausan secara tipikal diukur dengan menggunakan disc-on-disc dan disc skala kecil, dan koefisien gesek pada berbagai kondisi kontak dan beban juga diketahui. Gesekan dan pada kontak bergulir dan geser seperti pada kontak rel roda. Keausan roda dan relnya memerlukan investigasi lebih lanjut terhadap perilaku gesekan dan keausan pada kontak roda-kerel. Dengan pemahaman yang lebih baik tentang penyebabnya (friksi), akan memungkinkan untuk meletakkan konstruksi yang tepat pada efek (keausan) dan secara efektif melawan kerusakan pada komponen sistem [4].

Dalam merancang suatu mesin tribometer yang saling bergerak secara relatif antara satu dengan yang lainnya, maka perlu dilakukan pengukuran volume keausan atau laju keausan dan besarnya gaya gesek yang terjadi pada dua kontak permukaan yang saling bergerak relatif. Sementara umur elemen mesin dapat di tentukan dengan cara pengukuran geomteris. Untuk mengukur tingkat keausan akibat gesekan dan besar koefisien gesek yang terjadi dapat digunakan alat uji tribometer jenis discon-disc. Alat uji tribometer yang ada saat ini terbatas untuk pembebanan $500 \mathrm{MPa}$. Pada penelitian akan dikembangkan alat uji tribometer jenis disc-on-disc dengan pembebanan hingga $1000 \mathrm{MPa}$.

\section{TINJAUAN PUSTAKA}

Menggunakan metode Hertz untuk menetukan keausan kontak dalam simulasi keausan roda merupakan permasalahan antara perhitungan efisiensi dan akurasi, tetapi validasi diperlukan untuk membandingkan hasil simulasi dengan bidang yang diukur di lapangan [5].

Menentukan volume keausan roda digunakan untuk mengembangkan persamaan keausan berdasarkan model Archard dan mempertimbangkan faktor masa dari roda untuk memperkirakan pengaruh rasio creep, tekanan kontak dan kecepatan tangensial pada tingkat keausan tertentu. Hasil penelitian dibandingkan dengan hasil tes yang dilakukan di laboratorium. Telah mengalami perbedaan yang cukup kecil antara previsi dan tes laboratorium Mekanisme keausan dibahas dan dibandingkan dengan roda kereta api nyata menganalisis retakan kelelahan dan efek pengerasan regangan di bawah permukaan kontak terhadap roda dam rail [6].

Roda dan rel. Mempunyai kekuatan creep yang disebut Creep Tester seperti twin-disc rolling contact, Seiring dengan sejumlah fitur lainnya, seperti waktu pengukuran dan kemampuan untuk mengatur kekuatan normal, perangkat ini memudahkan dalam memastikan parameter yang mempengaruhi karakteristik gaya creep.terhadap kontak roda [7].

Mengetehui tekanan kontak dalam sistem roda rel dengan metode ultrasonik cara memindai daerah kontak yang dengan probe terfokus $10 \mathrm{MHz}$ dimungkinkan untuk menentukan variasi dalam refleksi gelombang ultrasonik, parameter yang diketahui terkait dengan keadaan kontak dari dua permukaan yang bersentuhan. Proses kalibrasi juga telah diatur, menerapkanteknik yang sama untuk kontak elastoplasma 'sphere versus plate' sederhana, menggunakan model FEM numerik untuk menghitung tekanan kontak untuk digabungkan dengan nilai-nilai refleksi yang terukur [8].

Metode pengujian sliding kembar telah dikembangkan untuk menilai efek residu dari berbagai kontaminan. Uji telah dilakukan pada berbagai nilai slip dan kurva creep telah dihasilkan.Pengujian kering, basah, dan minyak memberikan 
koefisien traksi dalam rentang yang serupa dengan pengujian sebelumnya. Kondisi kering memberi yang tertinggi nilai air dan minyak memberikan nilai yang lebih rendah [9].

\section{METODE PENELITIAN}

Pendekatan rancang bangun, tahap perancangan produk ini ada beberapa pemilihan konsep dengan metode matrik ini untuk menentukan keputusan beberapa konsep.

1. Alat dan bahan

2. Pembuatan mesin uji keausan

3. Persiapan dan peralatan

4. Pengujian mekanik

5. Verifikasi alat uji sesuai dengan fungsinya

Berikut ini adalah data pemilihan onsep desain dari penelitian sebelumnya dengan beberapa desain.

Tabel. 1. Matrik Keputusan Untuk Pemilihan Konsep Percancangan Alat Uji Keausan.

\begin{tabular}{|l|c|c|c|c|c|}
\hline \multicolumn{1}{|c|}{ Kriteria } & $\begin{array}{l}\text { Wt } \\
\text { \% }\end{array}$ & K1 & K2 & K3 & K4 \\
\hline $\begin{array}{l}\text { Putaran } \\
\text { Motor }\end{array}$ & 10 & 10 & 10 & 10 & 10 \\
\hline $\begin{array}{l}\text { Putaran } \\
\text { Spesimen } \\
\text { bisa di } \\
\text { monitor }\end{array}$ & 10 & 10 & 10 & 10 & 10 \\
\hline $\begin{array}{l}\text { Perubahan } \\
\text { Putran } \\
\text { spesimen } \\
\text { masing- } \\
\text { masing } \\
\text { berbeda. }\end{array}$ & 10 & 10 & 10 & 10 & 10 \\
\hline $\begin{array}{l}\text { Ukuran } \\
\text { Spesimen } \\
\text { konstan }\end{array}$ & 8 & 8 & 4 & 8 & 8 \\
\hline $\begin{array}{l}\text { Beban } \\
\text { Tekan bisa } \\
\text { di atur }\end{array}$ & 7 & 5 & 7 & 7 & 7 \\
\hline $\begin{array}{l}\text { Putaran } \\
\text { Beban torsi }\end{array}$ & 8 & 8 & 5 & 0 & 0 \\
\hline Antisipasi & 6 & 5 & 6 & 5 & 0 \\
\hline
\end{tabular}

\begin{tabular}{|l|c|c|c|c|c|}
\hline $\begin{array}{l}\text { poros } \\
\text { bending }\end{array}$ & & & & & \\
\hline $\begin{array}{l}\text { Mengurangi } \\
\text { slip }\end{array}$ & 8 & 8 & 5 & 0 & 4 \\
\hline $\begin{array}{l}\text { spesimen } \\
\text { Disk } \\
\text { kembar }\end{array}$ & 10 & 10 & 10 & 10 & 10 \\
\hline $\begin{array}{l}\text { Sistem } \\
\text { Pelumasan }\end{array}$ & 7 & 6 & 0 & 0 & 0 \\
\hline $\begin{array}{l}\text { Mudah } \\
\text { Dalam } \\
\begin{array}{l}\text { Pengoprasia } \\
\text { n }\end{array}\end{array}$ & 7 & 7 & 4 & 7 & 5 \\
\hline $\begin{array}{l}\text { Biaya } \\
\text { pembuatan } \\
\text { murah }\end{array}$ & 6 & 5 & 0 & 5 & 5 \\
\hline $\begin{array}{l}\text { Mudah } \\
\text { dalam } \\
\text { pembuatan }\end{array}$ & 10 & 10 & 0 & 0 & 10 \\
\hline Ergonomis & 8 & 5 & 6 & 7 & 5 \\
\hline $\begin{array}{l}\text { Praktis } \\
\text { penggunaan }\end{array}$ & 8 & 8 & 3 & 8 & 8 \\
\hline $\begin{array}{l}\text { Mudah } \\
\text { dalam } \\
\text { pemeliharaa } \\
\text { n }\end{array}$ & 7 & 7 & 5 & 6 & 7 \\
\hline $\begin{array}{l}\text { Adanya } \\
\text { Sensor }\end{array}$ & 10 & 10 & 10 & 10 & 10 \\
\hline $\begin{array}{l}\text { Jumlah } \\
\text { (50 }\end{array}$ & $\mathbf{1 3}$ & $\mathbf{1 1}$ & $\mathbf{1 1}$ \\
\hline
\end{tabular}

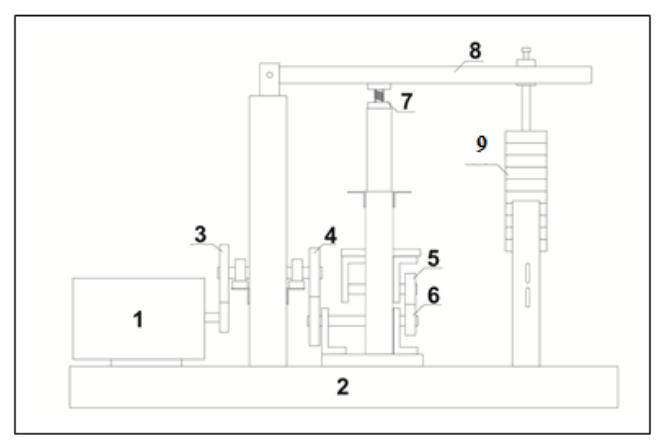

Gambar 1. Skema rancangan mesin Uji Keausan Disc-on-Disc

Keterangan :

1. Motor Penggerak

2. Frame

3. Roda Gigi Pembagi

4. Roda Gigi Pembagi

5. Rail spesimen 
6. Wheel Spesimen

7. Pegas

8. Batang Penghubung Beban

9. Pemberat

\section{Tempat dan Waktu Penelitian}

Tempat untuk memverifikasi alat uji Laboratorium Teknik Mesin Universitas Muhammadiyah Surakarta dan Laboratorium Teknik Mesin Universitas Diponoegoro Semarang. Waktu penelitian dilakukan 3 bulan untuk mendapatkan data.

\section{Alat dan Bahan}

1. Satu buah motor AC 3 phasa, $1 \mathrm{Hp}$.

2. Timbangan.

3. Tachometer.

4. Spaner

5. Holder

6. Roda Pembagi

7. Switching regulator: $12 \mathrm{~V}, 2$ Ampere.

8. Beban maksimal $20 \mathrm{~kg}$

9. Kabel: 4 wired, 4 color, diameter 0,4 $\mathrm{mm}$ dan $1,5 \mathrm{~mm}$.

10. Variable frequency Drive (VFD/Inverter), 3 phasa, 1,5 Hp.

11. Material spesimen VCL 140 dan EMS 45

\section{Perancangan Produk}

Pada tahapan perancangan produk, sistem dibagi menjadi:
a. Perancangan sistem mekanisme mesin uji keauasan.
b. Perancangan sistem mekanisme dilakukan berdasarkan fungsi utama dari mesin uji keauasan
c. yaitu menguji pasangan disc-on-disc untuk memperoleh koefisien gesek.
d. Perancangan sistem mekanisme beban.
e. Perancangan sistem display.
f. Perancangan sistem beban tekan.

\section{Pengujian alat uji keausan}

Hasil rancangan tersebut dapat berfungsi sesuai dengan yang di butuhkan Pengujian terhadap sebuah hasil rancangan diperlukan untuk menjamin bahwa keausan dapat di ketahui pada spesimen. Pada penelitian ini metode yang digunakan untuk metode eksperimen menguji hasil rancangan.

\section{Persiapan peralatan dan bahan}

Pada tahap pembuatan sistem mekanisme, putaran poros spesimen menggunakan transmisi roda gigi pembagi untuk menghindari slip, sistem ini digunakan agar slip pada poros sekecil mungkin dan tetapi kebisingan cukup tinggi.

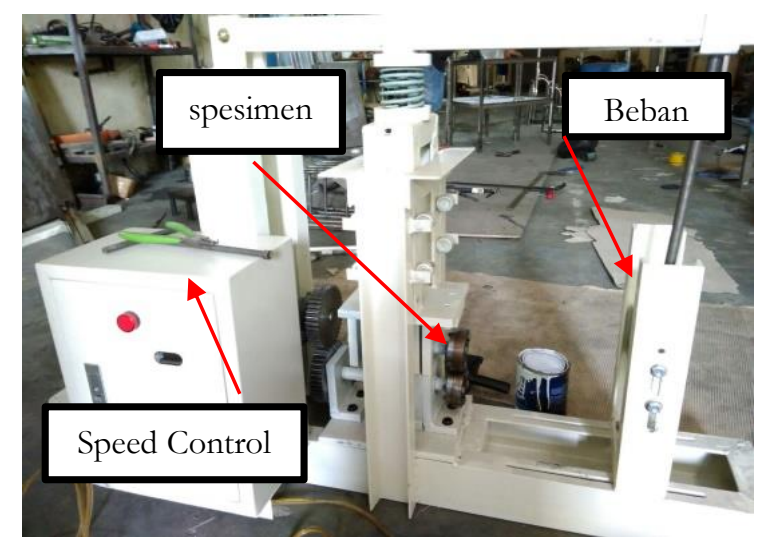

Gambar 2 Hasil Rancangan Uji Keausan

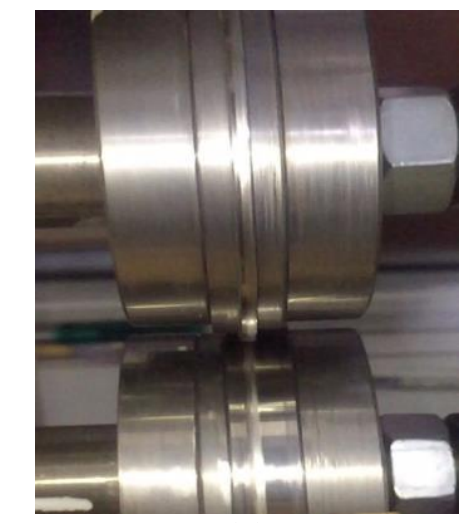

(a)

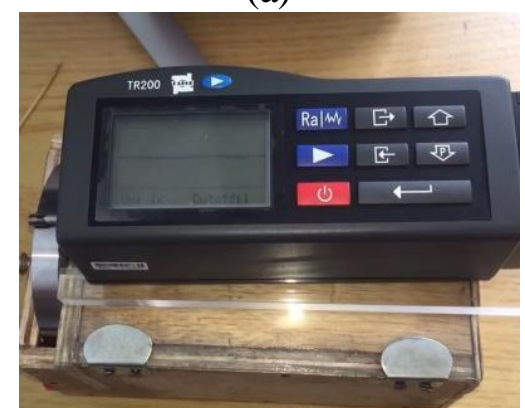

(b)

Gambar 3. disc-on-disc tribometer; (a) sampel disc atas dan bawah yang beroperasi, (b) Alat Pengukur Kontak dengan Profilometer (c) alat pengukur profilometer, yang dipasang di atas disc tes. 


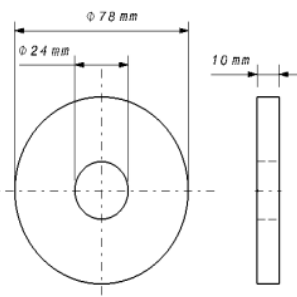

(a)

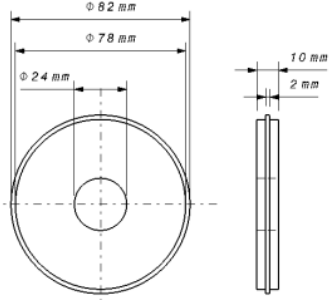

(b)
Gambar 4. (a), Spesimen Wheel (b) Spesimen Rail

Tabel. 2 Parameter Kekasaran Permukaan Spesimen Matrial EMS 45 (AISI 4140)

\begin{tabular}{|c|c|c|c|c|c|}
\hline $\begin{array}{c}\mathrm{Ra} \\
(\mu \mathrm{m})\end{array}$ & $\begin{array}{c}\mathrm{Rq} \\
(\mu \mathrm{m})\end{array}$ & $\begin{array}{c}\mathrm{Rz} \\
(\mu \mathrm{m})\end{array}$ & $\begin{array}{c}\mathrm{Rt} \\
(\mu \mathrm{m})\end{array}$ & $\begin{array}{c}\mathrm{Rp} \\
(\mu \mathrm{m})\end{array}$ & $\begin{array}{c}\mathrm{Rv} \\
(\mu \mathrm{m})\end{array}$ \\
\hline 0.5555 & 0.6699 & 3.095 & 4.059 & 1.496 & 1.600 \\
\hline
\end{tabular}

\section{Prosedur Pengujian}

Prosedur pengujian mengikuti tahapan-tahapan sebagai berikut:

a. Mengukur kekerasan spesimen.

b. Menentukan slip rasio dengan mengatur perbandingan jumlah putaran melalui speed control. Slip rasio dapat dihitung dengan persamaan model Archard (Meriam J. L., 2002):

$$
S=\frac{R_{w} \cdot W_{w}-R_{r} W_{r}}{R_{w} W_{w}} \times 100 \%
$$

c. Mengatur beban tekan $\left(\mathrm{F}_{\mathrm{N}}\right)$

d. Menentukan Koefesien Gesek

e. Menentukan Speed Control Pada Alat Uji Dengan Persamaan sebagai berikut.

\section{HASIL DAN PEMBAHASAN}

Hasil eksperimen yang berisikan memverifikkasi alat uji dengan peneliti seblumnya telah di lakukan pada hasil rancangan mesin uji keausan berbasis sistem kontak disk-on-disc yang dapat tunjukan sebagai berikut.

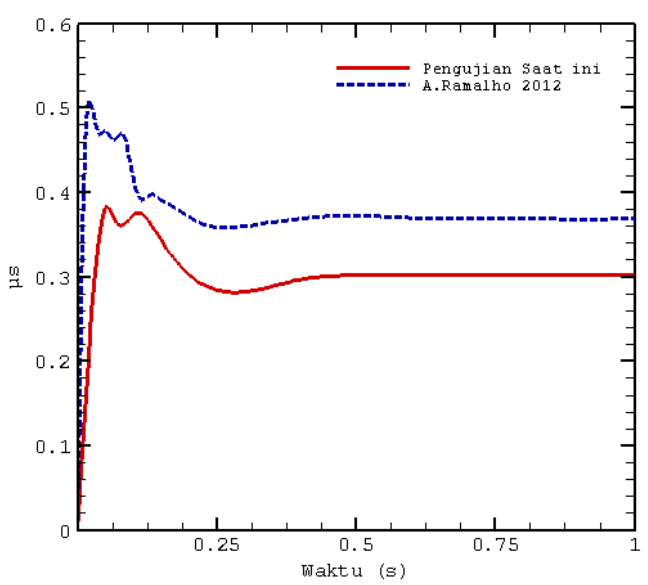

Gambar 5. Verifikasi Koefesien Gesek Alat uji disc-on-disc $1000 \mathrm{MPa}$

Setelah melakukan kalibarsi dengan alat uji seblumnya yang sudah di lakukan, maka alat ini layak di gunakan untuk melakukan pengujian keausan dengan sistem kontak dengan berbasis disc-on-disc dan koefisien gesek menjukan 0,4 dan di bandingkan peneliti sebelumnya 0,5 .

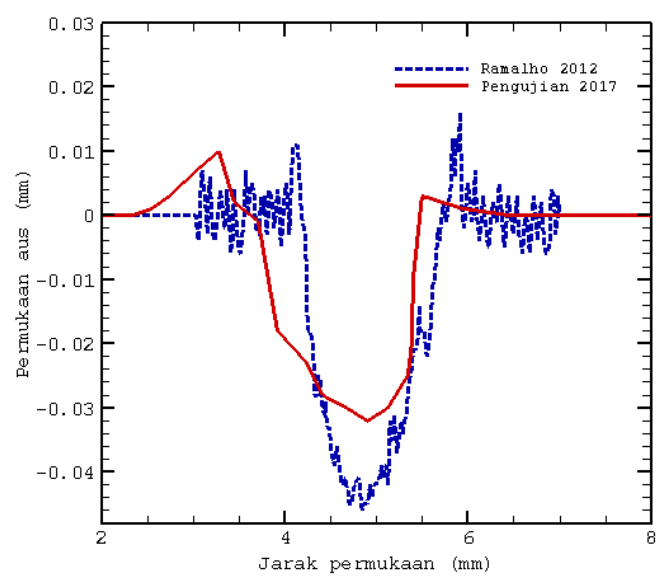

Gambar 6. Verifikasi Profil Kontak Keausan berbasis kontak disc-on-disc $1000 \mathrm{MPa}$

Gambar 6 verifikasi profil kontak alat uji, menunjukan speseimen mengalami tergerus nya akibat gesekan dan deformasi plastik $0.01 \mathrm{~mm}$ kedalaman tergerus 0.03 $\mathrm{mm}$. Sehingga alat uji layak di gunakan sebagai pengujian keausan sistem kontak berbasis disc-on-disc. 


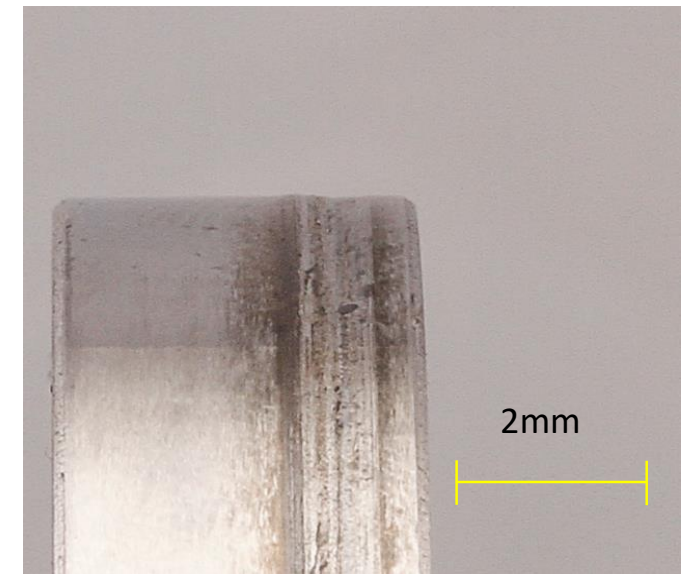

Gambar 7. Cacat akibat gesekan pada spesimen

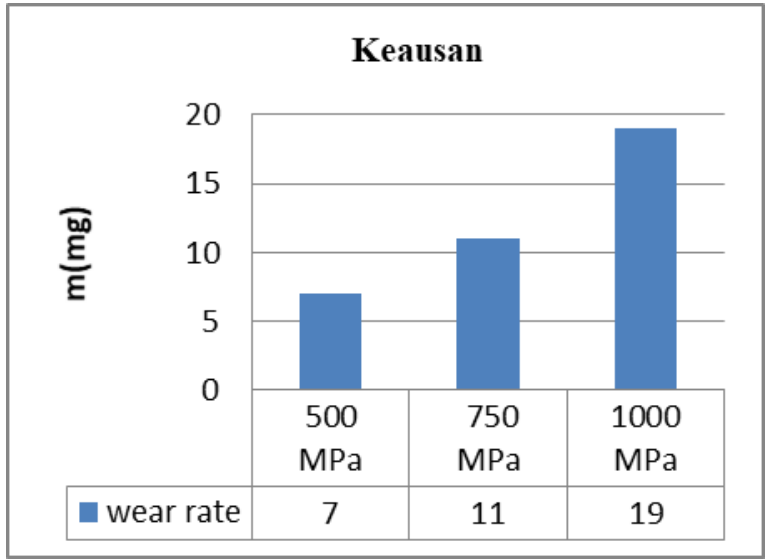

Gambar. 8 Keausan Dengan Kecepatan 1 m/s Tekanan Hingga 1000 Mpa
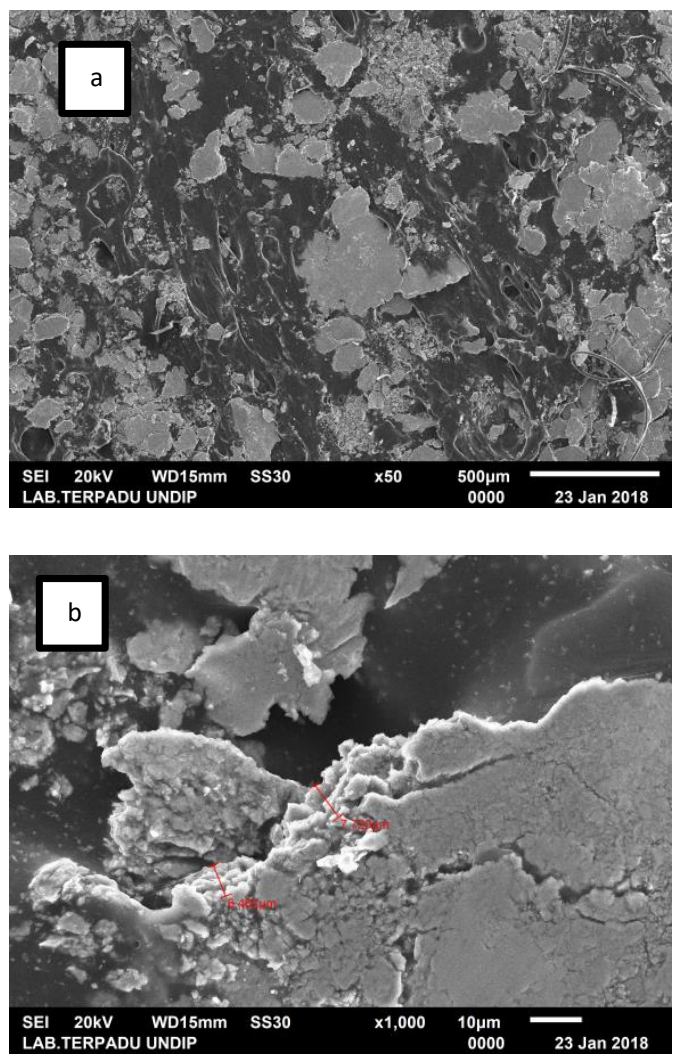
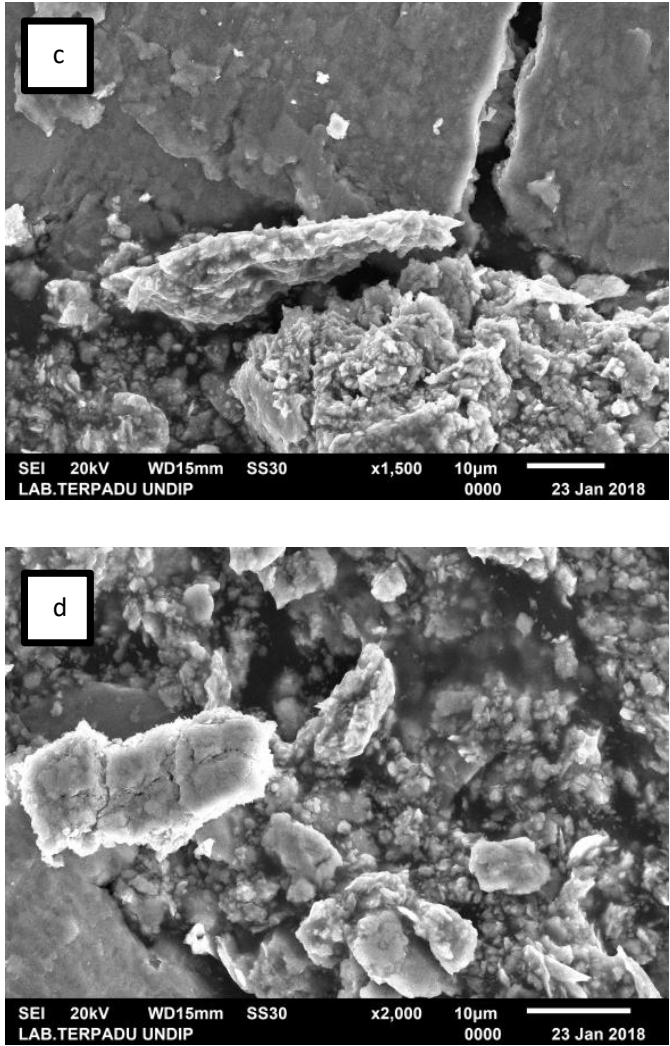

Gambar 9. Strukktur mikro puing-puing yang di peroleh dari SEM a) pembesaran objek 50x, b) pembesaran objek 1000x, c) pembesaran objek $1500 x$, d) pembesaran objek 2000x.

Gambar 9 Menjelaskan strukktur metalurgi puing - puing hasil gesekan rolling contact disc-on-disc tekanan 1000 $\mathrm{MPa}$ kecepatana $1 \mathrm{~m} / \mathrm{s}$ yang di peroleh dari SEM (scanning electron microscopes) puing-puing dari gesekan rolling contact ukuran tidak sama besar, bentuk ukuran dari puing itu sendiri tidak sama ada yang bentuknya butiran dan lempengan ini di akibatkan pembeban contact rolling tidak simteris dengan berjalannya waktu temperatur naik sendiri sehingga matrial mengalami deformasi plastik.

\section{Keutamaan alat uji}

Keutamaan dari alat uji keauasan ini diantaranya :

a. Dapat menghasilkan koefisien gesek dari contact rolling

b. Lama waktu pengujian yang dapat ditentukan dan daya tahan aus permukaan benda uji dengan berbagai 
variasi bahan dapat dengan mudah terdeteksi.

c. Pengujian dilakukan dengan mudah dan cepat terutama pergantian spesimen.

d. Benda uji tidak harus berukuran besar.

e. Perubahan tekanan, kecepatan dan jarak beban dapat dibuat dengan mudah dengan jarak yang begitu lebar.

\section{Kekuarangan alat uji}

Kekuarangan dari alat uji keausan ini diantaranya :

a. Pengukuran koefisien gesek yang begitu kurang sempurna dikarenakan alat yang di butuhkan sangat mahal dan sulit untuk di dapatkan.

b. Penerus daya yang digunakan adalah roda gigi sehingga menimbulkan suara.

c. Terdapat getaran jika proses pengujian berlangsung

d. Masih ada kebocoran arus listrik sehingga pada saat pengujian berlangsung

\section{KESIMPULAN DAN SARAN}

\section{Kesimpulan}

Berdasarkan hasil eksperimen yang dilakukan pada rancang bangun alat uji keausan berbasis sistem kotak disc-ondisc maka dapat disimpulkan:

a. Mesin hasil rancang bangun alat uji keausan berbasis sistem kontak discon-disc telah di validasi, maka mesin ini layak di gunakan untuk menguji keausan pada spesimen disc-on-disc dengan ukuran diameter minimal 78 mm maksimal $150 \mathrm{~mm}$, putaran yang dapat di variasikan mulai dari 0 hingga $280 \mathrm{rpm}$, dan tekanan dapat di variasikan $500 \mathrm{MPa}$ hingga $1000 \mathrm{MPa}$

b. Komponen utama mesin uji ini terdiri dari ,mesin tribometer, speed control ,inventer, dan jumlah tekanan. Hasil data yang akan di validasi adalah koefisien gesek $\left(\mu_{G}\right)$ dan profil kontak yang dari akhir gesekan.

c. Hasil pengujian menujukan keoefesien gesek tekanan hingga $500 \mathrm{MPa}$ dengan kecepatan $1 \mathrm{~m} / \mathrm{s}$ adalah $0,4 \%$ lebih tinggi dari Tekanan $1000 \mathrm{MPa}$ $0,8 \%$, dan ini menyebabkan koefisien gesekan dari gesekan rolling contact terkikisnya matrial di daerah permukaan disk dan geser gesekan untuk kekuatan tekanan $1000 \mathrm{MPa}$ dan kekasaran permukaan lebih kasar dari tekanan $500 \mathrm{MPa}$. Koefisien gesekan mulai dari 0,4 ke 0.25 dalam kondisi rolling contact dengan slip rasio $0,2 \%$ dari kecepatan disc.

d. Keausan pengurangan matrial akibat gesekan rolling contact Tekanan 500 $\mathrm{MPa}$, kecepatan 1m/s, 30.000 siklus dan waktu 240 menit. pengurangan matrial sebanyak $0,3 \%$, namun dengan tekanan $1000 \mathrm{MPa}$ adalah 0,8 \%, dapat di simpulkan bahwa nilai keausan semakin tekanan yang besar maka hilang matrial akibat gesekan semakin besar.

e. Strukutur mikro yang di peroleh dari SEM dengan variabel matrial tanpa berpelumas ukuran butiran puing tidak sama, dan bentuk puing ada yang berbentuk lempengan di sebabkan Gaya tekanan pada sepesimen tidak simteris, dan matrial mengalami perubahan temperatur dari akibat gesekan. Sedangkan puing berpelumas grafit puing dan grafit tidak homogen dengan material AISI 4140.

\section{Saran}

a. Pengukuran koefisien gesek yang begitu kurang sempurna di karenakan alat yang di butuhkan sangat mahal dan sulit untuk di dapatkan maka alat ini untuk lebih di sempurnakan nantinya.

b. Getaran dan suara yang sangat keras di akibatkan pergerakan transmisi pada roda gigi proses pengujian berlangsung, maka untuk itu penggerak seharusnya menggunakan pulley dan belt getaran dan suara berkurang.

c. Masih ada arus hubungan pendek pada saat pengujian berlangsung, 
maka alat perlu di tambahkan ground masa. wheel/rail adhesion," vol. 265, pp. 1309-1316, 2008.

\section{REFERENSI}

[1]. Y. Jin, M. Ishida, and A. Namura, "Experimental simulation and prediction of wear of wheel flange and rail gauge corner," Wear, vol. 271, no. 1-2, pp. 259-267, 2011.

[2]. R. H. I. JmcEwen, "Full scale wheelon rail wear testing," Wear, 2003.

[3]. K. DangVan M.H.Maitournam, "On some recent trends in modelling of contact fatigue and wear in rail," Wear, vol. 253, no. 1-2, pp. 219-227, 2002.

[4]. A.ShebaniS.Iwnicki, "Prediction of wheel and rail wear under different contact conditions using artificial neural networks," Wear, vol. https://do, 2018.

[5]. G. Tao, Z. Wen, X. Zhao, and X. Jin, "Author , S Accepted Manuscript Wear Simulation Reference: To appear in : Wear," Wear, 2016.

[6]. A.Ramalho, "Wear modelling in rail-wheel contact," Wear, vol. 330-331, pp. 524-532, 2015.

[7]. H. Doi, T. Miyamoto, Y. Nishiyama, S. Ohe, and H. Kamachi, "A new experimental device to investigate creep forces between wheel and rail," Wear, vol. 271, no. 1-2, pp. 40-46, 2011.

[8]. M. Pau, F. Aymerich, and F. Ginesu, "Distribution of contact pressure in wheel - rail contact area," vol. 253, pp. 265-274, 2002.

[9]. R. Lewis, "Twin disc assessment of 